\title{
Petroglifos pra um antigo-futuro
}

\section{Denilson Baniwa'}




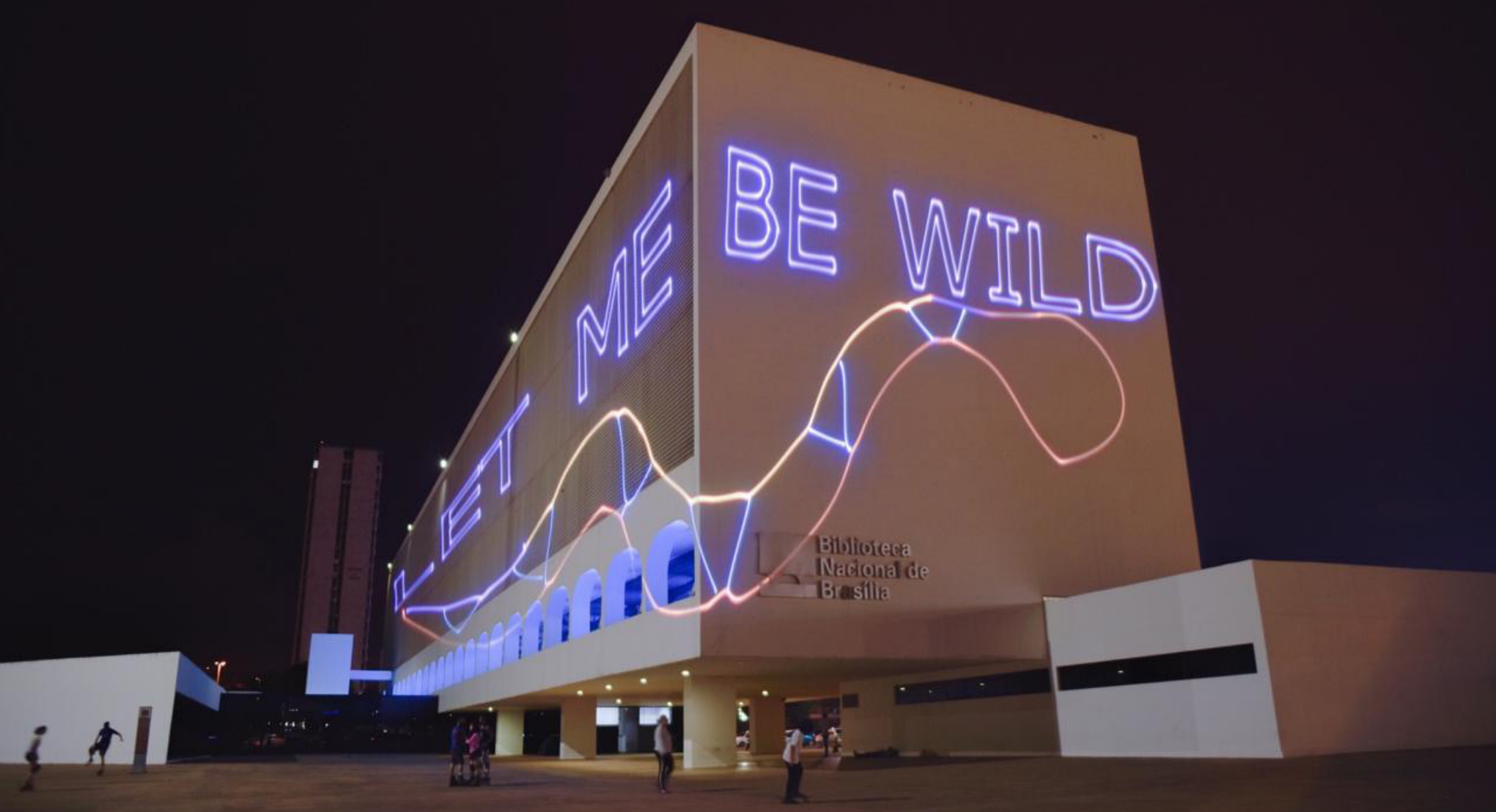

Figura 1 Os conhecimentos dos povos do Rio Negro, incluindo o povo a qual pertenDenilson Baniwa.

Me deixa ser selvagem, 2020 Acervo pessoal do artista. ço, estão gravados em rochas e acidentes geográficos ao longo do nosso território. São conhecimentos que contam a nossa cosmogonia, a narrativa de como o universo, o planeta e as humanidades foram criados. Além da oralidade, conhecemos nossa História através do que nossos antepassados deixaram escritos, por meios de signos ao longo dos tempos.

O acesso a tecnologias direcionadas a instrumentalização deste recurso narrativo possibilita apresentar de forma natural as entidades cosmogônicas aos centros urbanos, como São Paulo, transportando neste futuro o que foi perdido ao longo do caminho.

Os petroglifos saem de sua casa amazônica e chegam à urbanidade, visionando o que podemos nos tornar se esquecermos que somos parte da natureza e não donos da natureza. Ao mesmo tempo vêm contar a humanidade urbana o que eles esqueceram, e que talvez por algum momento seria bom reaprender sobre estas e outras humanidades.

No primeiro olhar, estas tecnologias podem parecer totalmente anti-indígenas 
ou não-indígenas, mas se olharem de onde estou, verão que já algum tempo tecnologias fazem parte do dia-a-dia da maioria das comunidades indígenas do Brasil, sejam por aliados brancos ou já utilizadas por elas próprias.

Tecnologias e novas mídias são um recurso importante para a defesa do nosso território, da nossa cultura e da nossa vida. É impossível hoje proteger nossas vidas sem conhecer sobre novas tecnologias, sejam de geoprocessamento, mídias digitais ou transmissão de dados, pois se ficarmos sem estes conhecimentos, seremos eliminados por agentes externos que não pouparão usar tecnologias e conhecimentos para nos cercear. Mesmo os povos que pouco se interessam ou desconhecem sobre estas ferramentas, hoje são protegidas por aliados que as fazem bom uso.

Um mural ou uma projeção usando canhões a laser no meio da cidade tem a intensão de quebrar as várias camadas de cimento e concreto que foram construídas em cima de memórias. De certa maneira, todo esse concreto e ferro, soterraram memórias antigas. É como se estivéssemos raspando camada, após camada até chegar no que um dia já foi natural. Pensando não como a fixação de uma nova camada, mas como um revelar de uma camada que estava soterrada, para reaparecem coisas que já havíamos esquecidos ou achávamos que estavam esquecidas.

Um petroglifo desenhado com laser no concreto da cidade é como uma cirurgia do globo ocular, ao mesmo tempo que queima, revela imagens que estavam turvas pela colonização que pouco a pouco foi tomando conta de nossas pupilas. É o reaparecimento de uma meta-ancestralidade dentro da matemática urbana colonial. 




Figura 2

Denilson Baniwa.

Me deixa ser selvagem, 2020.

Acervo pessoal do artista. 


\section{flashes in the sky of the memory}

antes do mundo éramos todos bicho-gente

um planeta-comum para viver

e falávamos o mesmo idioma

humano, paca, anta, jaguaretê

antes do mundo existir

meu tio era sucuri

minha tia taóka

meu avô urubu-rei

minha avó poraquê

meu irmão era samaúma

minha irmã tauari

minha prima mandioca

meu primo buriti

a civilização branca

quebrou o ciclo que meu povo protegeu

pouco a pouco eu vi meu mundo ruir

hoje chamo atenção ao céu

onde as grandes árvores-mágicas

seguram histórias antigas

de quando elas alimentavam

as gente-bicho do mundo

eu, você, eles, nós

o tempo das nossas avós

não mais em pedras escrevo estas histórias-ancestrais

com uma máquina-branca que aperta a luz e cria um foco

eu escrevo histórias do meu povo na selva de pedra urbana

e lembro da minha avó-gente

e lembro da minha avó-bicho

as duas revelo nos arranha-céus

pedindo aos brancos: olhem para o alto

onde ainda não alcançaram com seus concretos

olhem para os galhos das árvores-mágicas

que alimentam meu povo

desde quando o mundo ainda não existia 
enquanto jogo o canhão de laser

que desenha histórias-quase-esquecidas

no meu fone de ouvido toca

reflex in the sky

warn you you're gonna die

assim como nas minhas veias cabe

o sangue da minha avó-jaguar

e da minha avó-humana

entre meus petróglifos modernos

cabe também black sabbath 